THE CULTURE OF PROFESSION IN LATE RENAISSANCE ITALY 
This page intentionally left blank 


\section{The Culture of Profession in Late Renaissance Italy}

\section{George W. McClure}




\section{www.utppublishing.com}

(C) University of Toronto Press Incorporated 2004

Toronto Buffalo London

Printed in Canada

ISBN 0-8020-8970-4

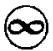

Printed on acid-free paper

\section{National Library of Canada Cataloguing in Publication}

McClure, George W., 1951-

The culture of profession in late Renaissance Italy / George W.

McClure.

Includes bibliographical references and index.

ISBN 0-8020-8970-4

1. Professions - Italy - History - 16th century. 2. Occupations Italy - History - 16th century. 3. Popular culture - Italy - History - 16th century. 4. Renaissance - Italy. 5. Italy-Social life and customs - 16th century. I. Title.

\section{DG445.M32 $2004 \quad 945^{\prime} .07 \quad$ C2004-900281-3}

University of Toronto Press acknowledges the financial assistance to its publishing program of the Canada Council for the Arts and the Ontario Arts Council.

University of Toronto Press acknowledges the financial support for its publishing activities of the Government of Canada through the Book Publishing Industry Development Program (BPIDP). 
To my parents, George and Martha 
This page intentionally left blank 